\title{
IN VITRO ANTI-INFLAMMATORY ACTIVITY TEST OF TINOCRISPOSIDE AND FREEZE-DRIED AQUEOUS EXTRACT OF TINOSPORA CRISPA STEMS ON HUMAN RED BLOOD CELL BY INCREASING MEMBRANE STABILITY EXPERIMENT
}

\author{
ADEK ZAMRUD ADNAN ${ }^{1 *}$, FITHRIANI ARMIN ${ }^{1}$, IKHWAN RESMALA SUDJI ${ }^{2}$, MEDIOLA DWI NOVIDA ${ }^{1}$, \\ DEWI IMELDA ROESMA ${ }^{3}$, HANA AFIFAH ALI ${ }^{1}$, ANNISA FAUZANA ${ }^{1}$
}

${ }^{1}$ Department of Pharmaceutical Chemistry, Faculty of Pharmacy, Andalas University, Padang, Indonesia. ${ }^{2}$ Department of Biomedical, Medical Faculty of Andalas University, Padang, Indonesia. ${ }^{3}$ Department of Biology, Andalas University, Padang, Indonesia. Email: adekzamrudadnan@phar.unand.ac.id

Received: 02 February 2019, Revised and Accepted: 27 March 2019

ABSTRACT

Objective: This study was aimed to evaluate the anti-inflammatory effect of isolated tinocrisposide and freeze-dried aqueous extract of Tinospora crispa stems on human red blood cell (HRBC) by increasing membrane stability in vitro models.

Methods: Anti-inflammatory effect of tinocrisposide and FDAETCS was evaluated by in vitro HRBC membrane stabilization method. The study was separated into two steps which were a hemolytic and a membrane stabilization experiment. The hemoglobin that was released throughout the damaged erythrocytes membrane was then quantified at the wavelength of $(\lambda) 560 \mathrm{~nm}$.

Results: The hemoglobin in the HBRC supernatant that treated with tinocrisposide at concentration of 100, 200, 400,600, 800, and 1000 $\mu \mathrm{g} / \mathrm{ml}$ showed an absorbance at $\lambda 560 \mathrm{~nm}$ of $0.060,0.061,0.071,0.072,0.075$, and 0.0793 , respectively, and the calculated hemolysis percentage was 0.032 , $0.097,1.203,1.236,1.641$, and $2.079 \%$, respectively. We found a linear correlation between concentration and hemolytic activity of tinocrisposide, with regression equation, $\mathrm{y}=0.0023 \mathrm{x}-0.1312(\mathrm{r}=0.929)$. Meanwhile, the HBRC supernatant that treated with FDAETCS at concentration of 100, 200, 400,600 , and $800 \mu \mathrm{g} / \mathrm{ml}$ showed an absorbance at $\lambda 560 \mathrm{~nm}$ of $0.063,0.064,0.066,0.067$, and 0.077 , respectively, and revealed the hemolytic percentage of $0.347,0.473,0.693,0.992$, and $1.896 \%$, respectively. It also gave a linear correlation between FDAETCS concentration and hemolytic activity percentage, with regression equation, $\mathrm{y}=0.002 \mathrm{x}+0.0222(\mathrm{r}=0.895)$. Moreover, in HRBC membrane stability experiment, tinocrisposide concentration of 100, 200, 400, 800, and $1000 \mu \mathrm{g} / \mathrm{ml}$ gave absorbance at $\lambda 560 \mathrm{~nm}$ of $0.818,0.808,0.798,0.789,0.773$, and 0.761 , respectively, and calculated HRBC membrane stabilization activity as much as 5.437, 6.533, 7.707, 8.748, 10.597, and 12.100\%, respectively. Meanwhile, the positive control ibuprofen $25 \mu \mathrm{g} / \mathrm{ml}$ only exerted the membrane stability of $5.620 \%$. It was found a linear correlation between tinocrisposide concentration and membrane stability percentage, with the regression equation, $y=0.0072 x+4.8312(r=0.9932)$. Treated FDAETCS in the concentration of 100 , 200,400 , and $800 \mu \mathrm{g} / \mathrm{ml}$ gave the absorbance at $\lambda 560 \mathrm{~nm}$ of $0.802,794,0.777,0.791$, and 0.792 , with stability membrane percentage of 7.283 , $8.208,10.944,8.555$, and $8.401 \%$, respectively. It can be seen that the FDAETCS concentrations and its hemolytic percentage showed a parabolic relationship, which gave a maximum at a concentration of the extract of $400 \mathrm{mg} / \mathrm{ml}$ with membrane stabilizing of $10.944 \%$.

Conclusion: It can be concluded that tinocrisposide and FDAETCS have an anti-inflammatory activity by increase the membrane stability of lysosome cell that has equal physiological properties with erythrocytes membrane cell and it has no hemolytic activity.

Keywords: Anti-inflammatory, Hemolytic, Human red blood cell, Membrane stabilization, Tinocrisposide, Tinospora crispa.

(C) 2019 The Authors. Published by Innovare Academic Sciences Pvt Ltd. This is an open access article under the CC BY license (http://creativecommons. org/licenses/by/4. 0/) DOI: http://dx.doi.org/10.22159/ajpcr.2019.v12i5.30690

\section{INTRODUCTION}

Tinospora crispa is a climber plant widely distributed from the Southwestern part of China to Southeast Asia including Indonesia, Malaysia, Vietnam, Thailand, and India. It naturally occurs in primary rainforests or mixed deciduous forests up to $1000 \mathrm{~m}$ above sea level [1]. T. crispa is well known as a bitter medicinal plant called Brotowali, Akar Seruntun, or Andawali in Indonesia, Akar Patawali in Malaysia, and Makabuhay in Philippine. A decoction of the stems has been traditionally used for the treatment of gout, diabetes, malaria, fever, wound healing, and hypertension, and scientifically reported as an analgesic and antiinflammatory agents [2].

T. crispa has been demonstrated to possess antioxidant, antiproliferative [3], antinociceptive [4], anti-inflammatory [5], antibacterial [6], antifilarial, antimalarial, antipyretic [7], and antihyperglycemic activities [8]. In our previous study from methanol extract of dried pulverized T. crispa stems, tinocrisposide $\left(\mathrm{C}_{27} \mathrm{H}_{36} \mathrm{O}_{11}\right)$ has been isolated, a furanoditerpene glycoside with a very bitter taste (Fig. 1) [9]. Furthermore, in our previous research, various concentrations of tinocrisposide were tested against the LPSstimulated RAW 264.7 cells, and the results showed the decrease of NO level production in concentration activity-dependent manner, with half-maximal inhibition concentration of $46.92 \mu \mathrm{M}$. Thus, it can be developed as anti-inflammatory candidate drug because NO is a reactive nitrogen species which is produced by NO synthase [10]. S. Chanda and A.R. Juvekar have tested in vitro anti-inflammatory activity of various concentrations of syringic acid by protein denaturation and human red blood cell (HRBC) membrane stabilization assay. The reference drugs used in experiments were aspirin and diclofenac sodium [11]. Meanwhile, Shamsi et al. studied anti-inflammatory activity of Joshanda, a polyherbal Unani formulation consists of seven plant ingredients by albumin denaturation inhibition experiment used aspirin as a reference compound [12]. In the current research, we are trying to prove the anti-inflammatory activity of tinocrisposide that can exert the increasing of HRBC membrane stability.

Inflammation is a normal protective response to tissue injury caused by physical trauma, destructive chemicals, or microbiological 
agents [13]. It is characterized by an alteration of immune system [14]. The inflammatory process is very closely related to wound healing. Inflammation and repair are a continuous process in wound healing involving inflammatory cells and enzymes. Cyclooxygenase (COX) family enzyme - COX-1 and COX-2 - is widely studied in inflammation disorder and critically responsible in the illness incident [15].

The inflammation, in general, is treated by nonsteroidal antiinflammatory drugs (NSAIDs) and steroidal anti-inflammatory drugs which are useful for reducing swelling and pain from inflammation. NSAIDs inhibit the COX enzyme which caused the conversion of arachidonic acid to prostaglandin become disrupted [16]. These drugs have a risk of gastrointestinal toxicity, cardiac toxicity, and others for prolonged use [17] so that traditional medicine or treatment from nature can be used as an alternative.

\section{MATERIALS AND METHODS}

\section{Plant materials}

T. crispa was collected from Padang, Indonesia. The plant specimens were properly identified and authenticated by Dr. Nurainas at the Department of Biology, Faculty of Science, Andalas University.

\section{Instruments}

UV lamp (Merck, Germany), pH meter, column chromatography (Pyrex), micropipette (Socorex), rotary evaporator (Bűchi), UV-visible spectrophotometer (Hitachi U-2910), Fourier-transform infrared spectroscopy (FTIR) Spectrum One (PerkinElmer), freeze dryer (Christ, Germany), water bath (Eyela SB-1000), centrifuge (Universal $32 \mathrm{R}$, Hettich Zentrifugen, USA), incubator (Thermo Scientific), microplate

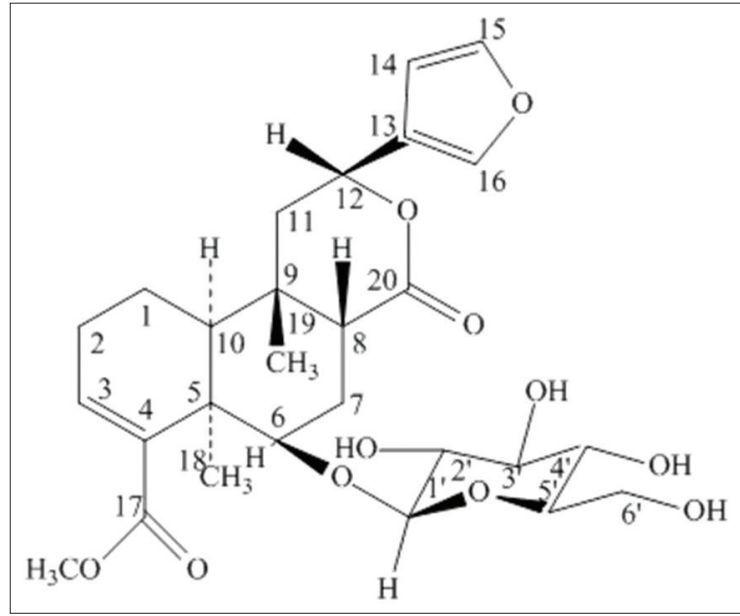

Fig. 1: Chemical structure of tinocrisposide [10] reader $\left(\right.$ BioRad $\times$ Mark $\left.^{\text {Tm}}\right)$, Falcon tube, Eppendorf tube, 96-well plate (Iwaki), and EDTA vacuum tube were used.

\section{Materials}

T. crispa stem, dichloromethane (DCM), methanol pro analysis (Merck), ethyl acetate (Merck), hexane (Merck), acetic acid (Merck), silica gel 60 $\mathrm{F}_{254}$ (Merck, Germany), TLC, sodium dodecyl sulfate (Sigma-Aldrich), isotonic $\mathrm{NaCl}$ solution (PT Widatra Bhakti), dimethyl sulfoxide (Thermo Fisher Scientific, USA), distilled water, ibuprofen, and human blood were used.

\section{Freeze-dried aqueous extract Tinospora crispa stems (FDAETPS)} preparation

Freshly collected stems were cut, shade-dried for 2-3 days, and ground into powder. It was then gently boiled with distilled water $11: 10)$ for $30 \mathrm{~min}$, filtered, and allowed to cool at room temperature. The filtrate was then freeze-dried at $-50^{\circ} \mathrm{C}$ and $0.1 \mathrm{~atm}$ for $9 \mathrm{~h}$, and stored at $4{ }^{\circ} \mathrm{C}$ before use.

\section{Tinocrisposide isolation}

The stems were cut, shade-dried, ground into powder, and macerated using methanol 3 times for 3 days each at room temperature. The extracts then evaporated under reduced pressure using a rotary evaporator to yield crude extracts. The extracts were dissolved in 5\% acetic acid and allowed overnight, decanted, and then partitioned, sequentially, with hexane and DCM. Each fraction was evaporated and dried to yield n-hexane, DCM fractions. The DCM fractions then subjected into column chromatography over silica gel 60 and eluted using step gradient elution (3-8\%) system with the mixture of DCM and methanol (3-8\% methanol) which were combined on the basis of thin-layer chromatography (TLC) evaluation. TLC was carried out using the mixture of $\mathrm{MeOH}$ : DCM (1:9) as a solvent system and the fractions with same Rf values were combined and further purified by column chromatography to obtain tinocrisposide as white amorphous powder [16]. The powder then identified using TLC, ultraviolet spectrophotometry, and FTIR spectroscopy.

\section{In vitro hemolytic test}

Blood from the healthy human volunteer who had not taken any NSAIDs for 2 weeks before the experiment was collected using vacutainer tube EDTA, mixed with isotonic $\mathrm{NaCl}$ solution, and centrifuged at $3000 \mathrm{rpm}$ for $5 \mathrm{~min}$. The packed cells were washed with isosaline and a 5\% HRBC suspension was made. Tinocrisposide $(100,200,400,600,800$, and $1000 \mu \mathrm{g} / \mathrm{ml})$ and FDAETCS $(100,200$, 400,600 , and $800 \mu \mathrm{g} / \mathrm{ml}$ ) were prepared in a distilled water. $0.5 \mathrm{ml}$ of sample was mixed with $0.5 \mathrm{ml}$ HRBC suspension in Eppendorf tubes and incubated at $37^{\circ} \mathrm{C}$ for $1 \mathrm{~h}$ [18]. After incubation, the tubes were centrifuged at $1000 \mathrm{rpm}$ for $5 \mathrm{~min}$ and the supernatant was transferred into 96-well plate. The absorbance of hemoglobin in the supernatant was measured at a wavelength, $\lambda$ of $560 \mathrm{~nm}$. As a positive

Table 1: Absorbance value of tinocrisposide and FDAETCS on hemolytic activity test

\begin{tabular}{|c|c|c|c|c|c|}
\hline \multirow[t]{2}{*}{ Sample } & \multirow[t]{2}{*}{ Concentration $(\mu \mathrm{g} / \mathrm{ml})$} & \multicolumn{4}{|c|}{ Absorbance } \\
\hline & & 1 & 2 & 3 & Mean \pm SD \\
\hline \multirow[t]{5}{*}{ Tinocrisposide } & 100 & 0.058 & 0.059 & 0.063 & $0.060 \pm 0.002$ \\
\hline & 200 & 0.061 & 0.064 & 0.058 & $0.061 \pm 0.003$ \\
\hline & 400 & 0.068 & 0.071 & 0.074 & $0.071 \pm 0.002$ \\
\hline & 600 & 0.068 & 0.079 & 0.069 & $0.072 \pm 0.007$ \\
\hline & 800 & 0.073 & 0.074 & 0.079 & $0.075 \pm 0.003$ \\
\hline \multirow[t]{5}{*}{ FDAETCS } & 100 & 0.063 & 0.062 & 0.065 & $0.063 \pm 0.002$ \\
\hline & 200 & 0.064 & 0.062 & 0.066 & $0.064 \pm 0.002$ \\
\hline & 400 & 0.066 & 0.070 & 0.063 & $0.066 \pm 0.004$ \\
\hline & 600 & 0.063 & 0.067 & 0.071 & $0.067 \pm 0.002$ \\
\hline & 800 & 0.079 & 0.077 & 0.076 & $0.077 \pm 0.002$ \\
\hline \multicolumn{2}{|c|}{ Negative control $(0.9 \% \mathrm{NaCl})$} & 0.060 & 0.061 & 0.060 & $0.060 \pm 0.001$ \\
\hline \multicolumn{2}{|c|}{ Positive control ( $5 \%$ SDS) } & 0.939 & 1.007 & 0.977 & $0.974 \pm 0.034$ \\
\hline
\end{tabular}


control, 5\% SDS was employed and an isotonic $\mathrm{NaCl}$ solution was used as a negative control. Measurements were replicated 3 times for each concentration [19]. The hemolytic activity was calculated with the following equation:

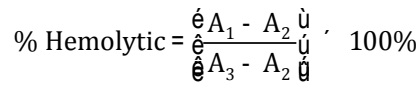

Table 2: Hemolytic activity percentage of tinocrisposide and FDAETCS on HRBC

\begin{tabular}{lll}
\hline Sample & Concentration $(\boldsymbol{\mu g} / \mathbf{m l})$ & Hemolytic activity $(\%)$ \\
\hline Tinocrisposide & 100 & 0.032 \\
& 200 & 0.097 \\
& 400 & 1.203 \\
& 600 & 1.236 \\
FDAETCS & 800 & 1.641 \\
& 1000 & 2.079 \\
& 100 & 0.347 \\
& 200 & 0.473 \\
& 400 & 0.693 \\
& 600 & 0.992 \\
& 800 & 1.896 \\
\hline
\end{tabular}

HRBC: Human red blood cell
Where, A1=Absorbance of test sample $\mathrm{A} 2=$ Absorbance of negative contro A3=Absorbance of positive control

\section{In vitro anti-inflammatory test}

This study was conducted using the HRBC membrane stabilization method. Blood from the healthy human volunteer who had not taken any NSAIDs for 2 weeks before the experiment was collected using vacutainer tube EDTA. Blood samples were mixed with isotonic $\mathrm{NaCl}$ solution and centrifuged at $3000 \mathrm{rpm}$ for $5 \mathrm{~min}$. The packed cells were washed with isosaline and a 10\% HRBC suspension was prepared [20]. Tinocrisposide $(100,200,400,600,800$, and $1000 \mu \mathrm{g} / \mathrm{ml})$ and freezedried aqueous extract $(2000,1000,800,600,400$, and $100 \mu \mathrm{g} / \mathrm{ml})$ were dissolved in a distilled water. Reaction mixtures consisted of $1 \mathrm{ml}$ test sample, $0.5 \mathrm{ml}$ of HRBC suspension, and $1.5 \mathrm{ml}$ distilled water. It was incubated at $37^{\circ} \mathrm{C}$ for $30 \mathrm{~min}$ and centrifuged at $3000 \mathrm{rpm}$. The hemoglobin content of the supernatant solution was measured spectrophotometrically at a wavelength $(\lambda)$ of $560 \mathrm{~nm}$. Measurements were replicated 3 times for each concentration. Ibuprofen that used as a standard and a control was made by substituting the test samples with isosaline [21]. The percentage of HRBC membrane stabilization was calculated using the following equation:

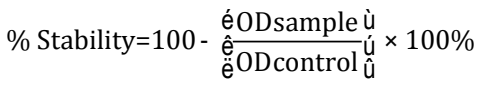

\begin{tabular}{|c|c|c|c|c|c|}
\hline \multirow[t]{2}{*}{ Tinocrisposide } & \multirow[t]{2}{*}{ Concentration $(\mu \mathrm{g} / \mathrm{ml})$} & \multicolumn{4}{|c|}{ Absorbance } \\
\hline & & 1 & 2 & 3 & Mean \pm SD \\
\hline & 100 & 0.817 & 0.819 & 0.817 & $0.818 \pm 0.001$ \\
\hline & 200 & 0.789 & 0.798 & 0.838 & $0.808 \pm 0.033$ \\
\hline & 400 & 0.777 & 0.820 & 0.798 & $0.798 \pm 0.022$ \\
\hline & 600 & 0.803 & 0.780 & 0.785 & $0.789 \pm 0.012$ \\
\hline & 800 & 0.741 & 0.788 & 0.791 & $0.773 \pm 0.028$ \\
\hline \multirow[t]{5}{*}{ FDAETCS } & 100 & 0.799 & 0.800 & 0.807 & $0.802 \pm 0.004$ \\
\hline & 200 & 0.781 & 0.792 & 0.808 & $0.794 \pm 0.014$ \\
\hline & 400 & 0.784 & 0.789 & 0.804 & $0.777 \pm 0.010$ \\
\hline & 600 & 0.724 & 0.795 & 0.855 & $0.791 \pm 0.066$ \\
\hline & 800 & 0.747 & 0.786 & 0.753 & $0.792 \pm 0.021$ \\
\hline \multirow[t]{3}{*}{ Ibuprofen } & 6.25 & 0.841 & 0.812 & 0.852 & $0.835 \pm 0.021$ \\
\hline & 12.5 & 0.836 & 0.870 & 0.792 & $0.832 \pm 0.039$ \\
\hline & 25 & 0.821 & 0.852 & 0.776 & $0.816 \pm 0.038$ \\
\hline
\end{tabular}

Table 3: Absorbance value of tinocrisposide and FDAETCS on HRBC membrane stabilization method

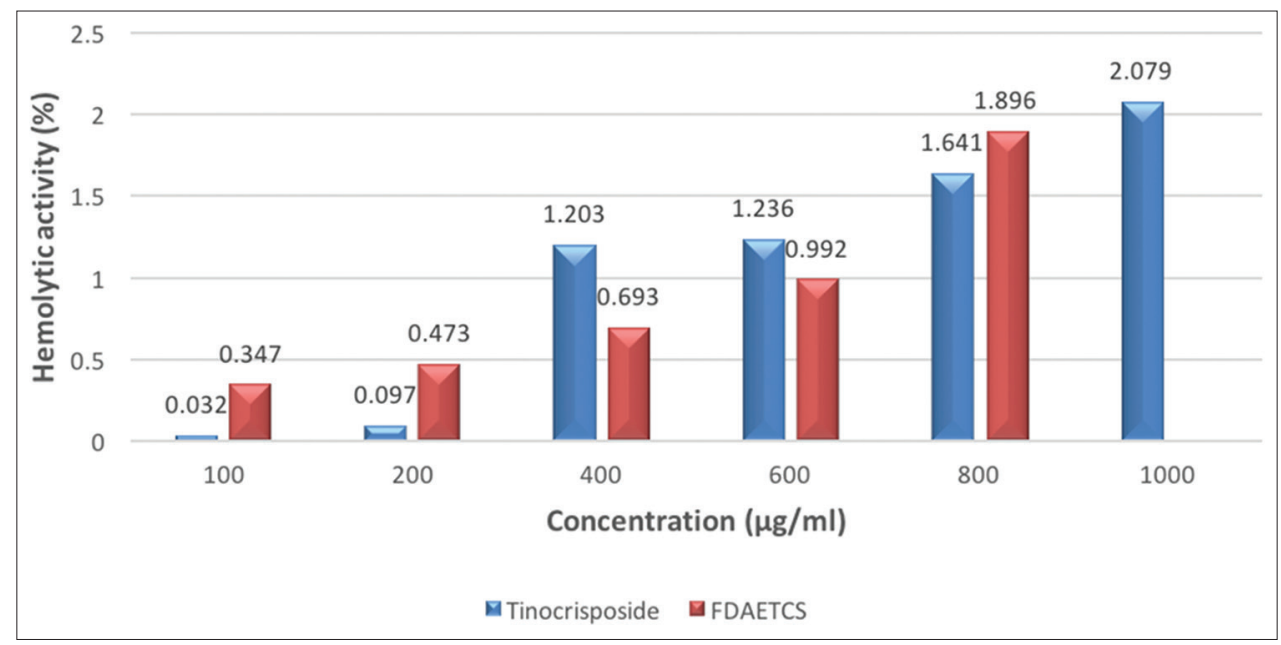

Fig. 2: Diagram of hemolytic activity percentage of tinocrisposide and FDAETCS on HRBC 
Data analysis

All data were expressed as means \pm standard deviation of result obtained from three independent experiments. Statistical analysis was performed using paired sample t-test. $P<0.05$ was considered statistically significant. The statistical package IBM SPSS Statistics Version 21 for Windows was used in the analysis.

\section{RESULTS AND DISCUSSION}

In vitro hemolytic test

The hemoglobin in the HBRC supernatant that treated with tinocrisposide at concentration of $100,200,400,600,800$, and $1000 \mu \mathrm{g} / \mathrm{ml}$ showed an absorbance of $0.060,0.061,0.071,0.072,0.075$, and 0.0793 , respectively. Meanwhile, the HBRC supernatant that treated with FDAETCS at concentration of $100,200,400,600,800,1000$, and $2000 \mu \mathrm{g} / \mathrm{ml}$ showed an absorbance of $0.063,0.064,0.066,0.067$, and 0.077 , respectively (Table 1 ).

The percentage of calculated hemolytic activity of various concentrations of tinocrisposide and FDAETCS on HRBC is presented in Table 2.

Data in Table 2 showed that hemolytic activity percentage of tinocrisposide in the concentration of $100,200,400,600,800$, and 1000 $\mu \mathrm{g} / \mathrm{ml}$ on HRBC was $0.032,0.097,1.203,1.236,1.641$, and $2.079 \%$, respectively. We found a linear correlation between tinocrisposide concentration and hemolytic activity percentage, with regression equation, $y=0.0023 x-0.1312$, and coefficient correlation, $R=0.929$. The same condition occurs in the FDAETCS that at the concentration of $100,200,400,600$, and $800 \mu \mathrm{g} / \mathrm{ml}$ showed the hemolytic percentage of $0.347,0.473,0.693,0.992$, and $1.896 \%$, respectively. It also gave a linear correlation between FDAETCS concentration and hemolytic activity percentage, with regression equation, $y=0.002 x+0.0222$, and coefficient correlation, $\mathrm{R}=0.895$.

Table 4: Membrane stability percentage of various concentrations of tinocrisposide and FDAETCS

\begin{tabular}{lll}
\hline Sample & Concentrations $(\boldsymbol{\mu g} / \mathbf{m l})$ & $\begin{array}{l}\text { Membrane } \\
\text { stability (\%) }\end{array}$ \\
\hline Tinocrisposide & 100 & 5.437 \\
& 200 & 6.533 \\
& 400 & 7.707 \\
& 600 & 8.748 \\
FDAETCS & 800 & 10.597 \\
& 1000 & 12.100 \\
& 100 & 7.283 \\
& 200 & 8.208 \\
& 400 & 10.944 \\
Ibuprofen & 600 & 8.555 \\
& 800 & 8.401 \\
& 25 & 5.620 \\
\hline
\end{tabular}

Fig. 2 showed a clear comparison of hemolytic activity between tinocrisposide and FDAETCS in various concentrations. Hemolytic percentage with a value of $<10 \%$ was interpreted as non-hemolytic, and a value of $>25 \%$ was considered showing hemolytic effect. From the experiments, it is showed that tinocrisposide and FDAETCS have no hemolytic effect with a percentage value of $<10 \%$ and no toxicity on HRBC so that this compound can later be used for drug formulations. Erythrocyte membrane is analogous to the lysosomal membrane, so compounds that caused a damage to erythrocyte membrane will also damage lysosomal membrane [22].

\section{In vitro anti-inflammatory test}

Tinocrisposide and FDAETCS were tested if they are able to prevent water-induced lysis of red blood cells using membrane stabilization assay. The result of the HRBC membrane stabilization test is shown in Table 3.

Table 3 showed that by treating tinocrisposide in the concentration of $100,200,400,800$, and $100 \mu \mathrm{g} / \mathrm{ml}$ on HRBC membrane stabilization experiment will give the absorption of hemoglobin at wavelength, $\lambda$ $560 \mathrm{~nm}$ by $0.818,0.808,0.798,0.789,0.773$, and 0.761 , respectively, with stability membrane by $5.437,6.533,7.707,8.748,10.597$, and $12.100 \%$, respectively. Meanwhile, the positive control ibuprofen $25 \mu \mathrm{g} / \mathrm{ml}$ only exerted the membrane stability of $5.620 \%$ (Table 4 ). We found a linear correlation between tinocrisposide concentration and membrane stability percentage, with the regression equation, $y=0.0072 x+4.8312$, and the coefficient correlation, $R=0.9932$ (Fig. 4).

Data in Table 3 showed that by treating tinocrisposide in the concentration of $100,200,400,800$, and $1000 \mu \mathrm{g} / \mathrm{ml}$ on HRBC membrane stabilization experiment will give the absorbance of hemoglobin at wavelength $(\lambda) 560 \mathrm{~nm}$ by $0.802,794,0.777,0.791$, and 0.792 , respectively, with stability membrane by $7.283,8.208,10.944$, 8.555 , and $8.401 \%$, respectively. It can be seen that the relationship between FDAETCS and its membrane stability percentage is parabolic, which gave a maximum at a concentration of the extract of $400 \mathrm{mg} / \mathrm{ml}$ with membrane stabilizing of $10.944 \%$. This phenomenon is assumed because the extract also contains other compounds that can cause inflammatory or hemolysis of membrane erythrocytes. Tinocrisposide at the concentration of $100 \mu \mathrm{g} / \mathrm{ml}$ had HRBC membrane stability of $5.437 \%$ that close to membrane stability of the positive control, ibuprofen at the concentration of $25 \mu \mathrm{g} / \mathrm{ml}$ that revealed membrane stability of $5.620 \%$. It means at those concentrations the efficacy of tinocrisposide was $96.74 \%$ of ibuprofen. If membrane stability of tinocrisposide compared to FDAETCS membrane stability, it can be seen an interesting phenomenon, namely, FDAETCS in the level concentration of $100-400 \mu \mathrm{g} / \mathrm{ml}$ showed higher efficacy then tinocrisposide, but in the higher concentration, tinocrisposide revealed evidently higher efficacy than FDAETCS did (Table 4 and Fig. 3).

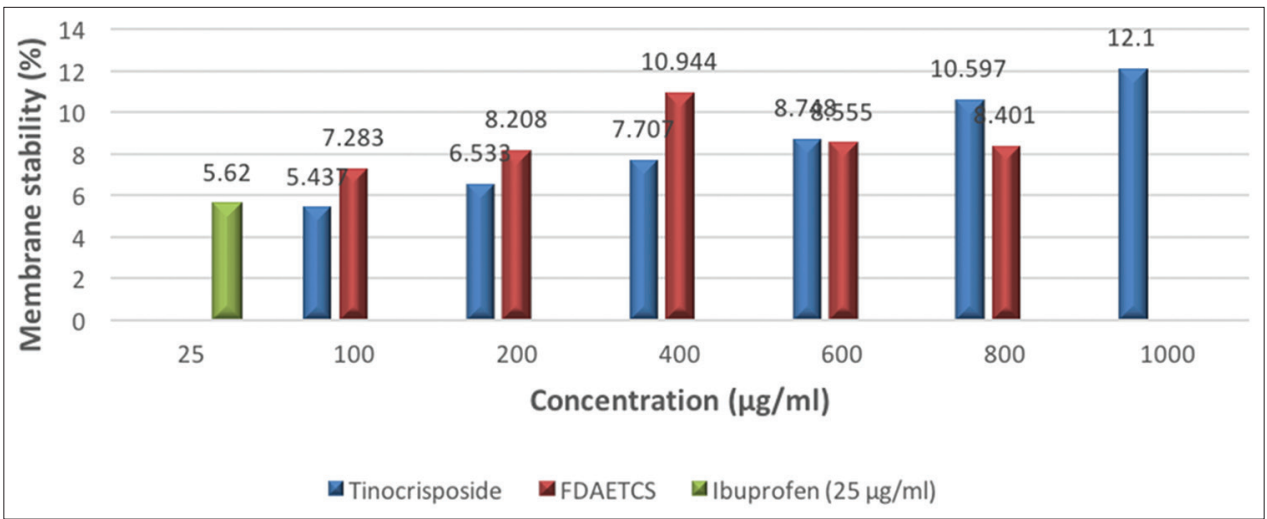

Fig. 3: Membrane stability percentage (\%) of tinocrisposide, FDAETCS, and ibuprofen 


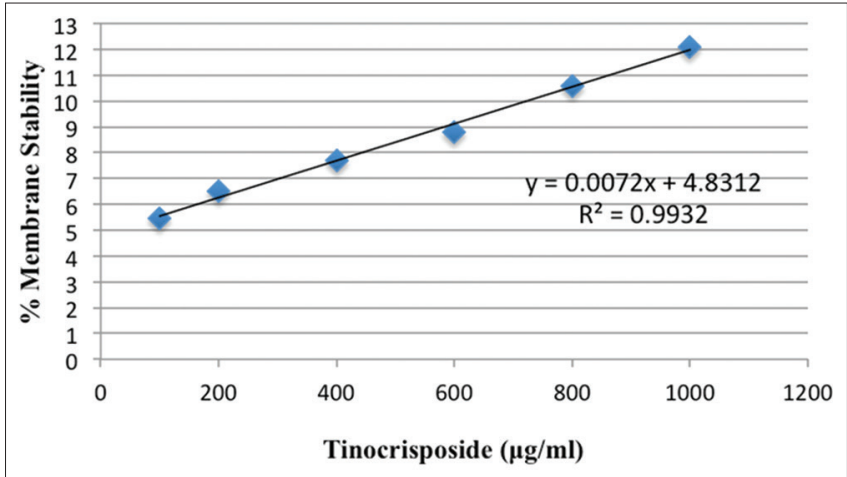

Fig. 4: Diagram between tinocrisposide concentrations versus membrane stability percentage

Anti-inflammatory agents control the biochemical processes involved during the inflammatory response by stabilizing the membranes of lysosomes [18]. The erythrocyte membrane is analogous to the lysosomal membrane, and its stabilization implies that tinocrisposide and FDAETCS may as well stabilize lysosomal membranes [23]. Stabilization of lysosomal membrane is important in limiting the inflammatory response by preventing the release of lysosomal constituents of activated neutrophils such as bactericidal enzymes and proteases, which cause further inflammation and damage on extracellular release [24].

In this study, distilled water was used as an inductor that triggers hemolysis that can cause the release of inflammatory mediators. By adding $1.5 \mathrm{ml}$ of distilled water into the well plate, it will decrease an osmotic pressure solution outside of the erythrocyte cell, while in the cell, it remains equivalent to $0.9 \% \mathrm{NaCl}$ solution. Then, the water from outside of the cell will move into the cell, across the erythrocytes cell membrane which functions as a semipermeable membrane, this causes the swelling of the cell, and eventually rupture and hemolysis. In human body, an inflammatory mediator actually plays an important role in preventing the spread of infection and is also needed to repair tissue damage [18]. However, excessive inflammatory mediators can cause tissue damage and chronic inflammation [25].

\section{CONCLUSION}

It can be concluded that tinocrisposide and FDAETPS stem have an antiinflammatory activity by increase the membrane stability of lysosome cell that has equal physiological properties with erythrocytes membrane cell and it has no hemolytic activity; therefore, tinocrisposide can be promoted and developed as a new anti-inflammatory drug candidate.

\section{ACKNOWLEDGEMENT}

The authors would like to thank Andalas University, Padang, Indonesia, for the grant given to conduct this research.

\section{AUTHORS' CONTRIBUTIONS}

Conception and design of study: A.Z. Adnan, I.R. Sudji, D.I. Roesma, and M.D. Novida. Acquisition of data: M.D. Novida and H.A. Ali. Analysis and interpretation of data: A.Z. Adnan, M.D. Novida, D.I. Roesma, and A. Fauzana. Drafting the manuscript: F. Armin, M.D. Novida, and A. Fauzana. Revising the manuscript critically for important intellectual content: A.Z. Adnan and I.R. Sudji.

\section{CONFLICTS OF INTEREST}

The authors declare that they have no conflicts of interest.

\section{REFERENCES}

1. Dweck AC, Cavin JP. Andawali (Tinospora crispa): A review. Front Pharmacol 2006;7:33-9.

2. Abu MN, Mohd Salleh AM, Mohd Radzman NH. Insulin sensitivity enhancement of the mixture of Tinospora crispa and gelam (Melaleuca cajuputi) honey and its antiproliferative activity on hepatocellular carcinoma, HepG2: A preliminary study. J Med Res Dev 2013;2:48-54

3. Zulkhairi A Jr., Abdah MA, Kamal NH, Nursakinah I, Moklas MA, Hasnah B, et al. Biological properties of Tinospora crispa (Akar Patawali) and its antiproliferative activities on selected human cancer cell lines. Malays J Nutr 2008;14:173-87.

4. Sulaiman MR, Zakaria ZA, Lihan R. Antinociceptive and antiinflamatory activities of Tinospora crispa in various animal models. Int J Topical Med 2008;3:66-9.

5. Yokozawa T, Wang TS, Chen CP, Hattori M. Inhibition of nitric oxide release by an aqueous extract of Tinospora tuberculata. Phytother Res 2000; $14: 51-3$

6. Zakaria ZA, Mat Jais AM, Henie EF, Zaiton H, Somchit MN, Sulaiman MR, et al. The in vitro antibacterial activity of Tinospora crispa extracts. J Biol Sci 2006;6:398-401.

7. Kongkathip N, Dhumma-upakorn P, Kongkathip B, Chawananoraset K, Sangchomkaeo P, Hatthakitpanichakul S. Study on cardiac contractility of cycloeucalenol and cycloeucalenone isolated from Tinospora crispa. J Ethnopharmacol 2002;83:95-9.

8. Noor H, Ashcroft SJ. Pharmacological characterisation of the antihyperglycaemic properties of Tinospora crispa extract. J Ethnopharmacol 1998;62:7-13.

9. Pachaly P, Adnan AZ. Tinocrisposide, a new furanoditerpene glycoside from Tinospora crispa. Arch Pharm (Weinheim) 1992;325:705-8.

10. Adnan AZ, Taher M, Afriani T, Fauzana A, Roesma DI, Putra AE. Anti-inflamatory activity of tinocrisposide by inhibiting nitric oxide production in lipopolysaccharides-stimulated raw 264.7 cells. Asian J Pharm Clin Res 2018;11:149-53.

11. Chandra S, Juvekar AR. In vitro anti-inflammatory activity of syringic acid. Int J Pharm Pharm Sci 2018;11:71-3.

12. Shamsi TN, Parveen R, Sajida A, Ahmad A, Fatima S. Assessing the therapeutic role of Joshanda: Phytochemical, antioxidant, antiinflammatory and antimicrobial activities. Int $\mathrm{J}$ Pharm Pharm Sci 2018; 10:122-8.

13. Nathan C. Points of control in inflammation. Nature 2002;420:846-52

14. Hotamisligil GS. Inflammation and metabolic disorders. Nature 2006;444:860-7.

15. Chen C. COX-2's new role in inflammation. Nat Chem Biol 2010;6:401-2.

16. Katzung BG. Basic and Clinical Pharmacology: $10^{\text {th }}$ ed. San Francisco, USA: McGraw Hill Lange; 2006.

17. Katzung BG. Basic and Clinical Pharmacology. $12^{\text {th }}$ ed. New York: McGraw Hill Lange; 2012.

18. Kumar V, Bhat ZA, Kumar D, Khan NA, Chashoo IA. Evaluation of anti-inflammatory potential of leaf extracts of Skimmia anquetilia. Asian Pac J Trop Biomed 2012;2:627-30.

19. Minegishi T, Nakamura K, Yamashita S, Ikeda S, Kogure K. Regulation of human luteinizing hormone receptor in the ovary. Reprod Med Biol 2008:7:11-6.

20. Saleem TK, Azeem AK, Dilip C, Sankar C, Prasanth NV, Duraisami R. Anti-inflammatory activity of the leaf extacts of Gendarussa vulgaris nees. Asian Pac J Trop Biomed 2011;1:147-9.

21. Sudji IR, Subburaj Y, Frenkel N, García-Sáez AJ, Wink M. Membrane disintegration caused by the steroid saponin digitonin is related to the presence of cholesterol. Molecules 2015;20:20146-60.

22. Hipol RL, Cariaga MF, Hipol RM. Anti-inflammatory activities of the aqueous extract of the stem of Tinospora crispa (Family Menispermaceae). J Nat Stud 2012;11:88-95.

23. Kumar P, Arora S, Yadav YC. Anti-inflammatory activity of coumarin and steroidal fractions from leaves of Moringa oleifera. Int J Drug Discov Med Res 2012;1:22-5.

24. Bakkali F, Averbeck S, Averbeck D, Idaomar M. Biological effects of essential oils - a review. Food Chem Toxicol 2008:46:446-75.

25. Serhan CN. System approach to inflammation resolution: Identification of novel anti-inflammatory and pro-resolving mediators. J Thromb Haemost 2009;7 Suppl 1:44-8. 